
\title{
R Research S Suare \\ The Response Shift in Quality of Life Assessment among Patients with End-Stage Renal Disease: A Systematic Review
}

\section{Zheng Yang}

Tsinghua University Graduate School at Shengzhen

Fei Yang ( $\sim$ daodanyydy163@163.com )

Tsinghua University https://orcid.org/0000-0001-8234-5616

Qian Lin

Tsinghua University Graduate School at Shengzhen

\section{Xiaoru Feng}

Tsinghua University Graduate School at Shengzhen

\section{Ying Kong}

Tsinghua University Graduate School at Shengzhen

\section{Research Article}

Keywords: Response shift, Health-related quality of life, End-stage renal disease, Dialysis, Renal transplantation Posted Date: May 13th, 2021

DOI: https://doi.org/10.21203/rs.3.rs-207108/v1

License: (c) (i) This work is licensed under a Creative Commons Attribution 4.0 International License. Read Full License 


\section{Abstract \\ Purpose}

The remarkable impact of response shift on quality of life $(\mathrm{Q} o \mathrm{~L})$ assessment among patients has been cited. There is an increased emphasis on distinguishing the real change of QOL and the self-regulation of individuals. This study aims to review the evidence of the response shift among patients with end-stage renal disease (ESRD).

\section{Methods}

We conducted searches of five electronic databases, including PubMed, EMBASE, EBSCO host, Web of Science, Cochrane Library, manual review. Articles published up to 13 May 2020 were selected. Studies meeting the eligibility criteria were reviewed according to Preferred Reporting Items for Systematic reviews and Meta-Analyses (PRISMA) guidelines. The quality of included articles was assessed using the National Institutes of Health Quality Assessment Tool for Observational Cohort and Cross-Sectional Studies.

\section{Results}

The search of databases yielded 121 articles and articles were included in this review. of them were quantitative prospective cohort studies and one was a qualitative perspective cross-sectional study. The QoL measurements included visual analog scale, time trade-off, standard gamble, individual interviews, the Schedule for Evaluation of Individual Quality of Life-Direct Weighting (SEIQoL-DW) and the ideal scale. A total of individuals was included, and the most common participants enrolled in these studies were patients with dialysis (studies). All of the eligible studies reported the use of then-test methods and of them used individualized measures including interviews, SEIQol-DW and ideal scale to examine response shifts. The existence of response shift was reported in each study and the most common type of response shifts detected was recalibration. The disease trajectory and have-want discrepancy of individuals were revealed as important factors of response shifts.

\section{Conclusions}

Our systematic review indicated that the response shift in QoL assessment among patients with ESRD was proved to exist and need more attention. What's more, making use of response shifts to modify interventions may promote recovery and help patients adapt to illness better. Present studies were limited by the sample size, research design and response shift detection methods. Further work on advanced research design and RS detection methods is needed in the context of ESRD.

\section{Introduction}

Patient-reported outcomes (PRO) are obtained directly from patients and provide their physical and mental health state, quality of life (QoL), and treatment experience, which are of increasing importance in patient-centered care [1,2]. However, the interpretation of PRO has never been monotonous from a long-term perspective. The meaning of patients' self-evaluated QoL may change across the adaptation to disease or time, which is now typically known as response shift (RS) and first put forward by Sprangers and Schwartz [3]. According to them, response shift arises when: (1) people alter the internal measuring standards of their quality of life (recalibration); (2) people change their priority of items when evaluating their quality of life (reprioritization); (3) people change their perception of 
conceptualization (reconceptualization) [3]. RS must be considered when evaluating medical treatment and providing psychological support. There exist several reasons. First, the response shift may cover up the real change of healthrelated quality of life (HRQoL) and lead to a misunderstanding of toxic and side effects of treatment, thus overstating or attenuating the therapeutic effects $[4,5]$. Secondly, psychosocial interventions based on response shift might help patients positively adapt to the change of health conditions [6]. For instance, through mutual assistance, patients might perceive their quality of life as acceptable, since the peers' worse situation lowers their internal standards. Besides, guidance on reconsidering a feasible goal or definition of good-quality life may also take effect.

Patients with end-stage renal disease (ESRD) are generally treated with various renal replacement therapies (RRT), including hemodialysis (HD), peritoneal dialysis (PD), and renal transplantation (Tx) [7]. The impaired HRQoL of patients with ESRD are well documented and nephrologists should pay attention to both the clinical and biological outcomes, and the HRQoL [8]. The occurrence of RS among ESRD patients may vary with the RRT modalities and affect their adaption and experience [9]. Those dependent on dialysis typically will see their functional performance and well-being under sustaining damage [10]. As the disease progresses, the conditions of health and HRQoL get worse and psychological adjustments will be involved, which might result in a biased report of the perceived HRQoL [11]. As for Tx patients, the confounding effects of psychological factors also exist. Compared with those who transform dialysis to kidney transplantation, patients preemptively undergoing kidney transplantation may regard transplantation as a signal of health deterioration and the cause of their psychological burden and body pain even though they are in good condition. Those who have experienced a period of dialysis-dependent life may adapt to the transplantation more easily and also report a better quality of life [12]. Thus, the response shift among patients with ESRD needs further discussion to clarify the real change of their HRQoL and improve their adaption to the RRT modalities.

However, all the previous studies tend to mainly investigate the response shift phenomenon among patients with cancer and chronic diseases such as kidney disease and Parkinson's disease [11-18]. To our knowledge, there are only six systematic reviews on the study of RS, the topics of which include RS among cancer patients, RS after rehabilitation for orthopedic disorders, the clinical significance of RS, and RS detection methods, while none of them concerned patients with ESRD. [13-14, 19-22]. This study is the first and aimed to review the evidence, study design, detection methods, participants' characteristics, primary results, and conclusions of RS among ESRD patients. Furthermore, we summarized the factors contributing to the emergence and mechanism of RS and pointed out the possible directions for further research.

\section{Methods}

\section{Search strategy}

This systematic review was reported in accordance with the Preferred Reporting Items for Systematic reviews and Meta-Analyses (PRISMA) guidelines [23]. We searched the PubMed, EMBASE, EBSCO host, Web of Science, and Cochrane Library from its inception until 13 May 2020, using the Medical Subject Headings (MeSH) and text words related to three modalities, along with end-stage renal disease, renal replacement therapy and response shift as keywords. The search strategy is available in Additional file 1.

\section{Eligibility criteria and study selection}

The studies satisfying the following criteria were included: (1) all patients were pathologically confirmed to have ESRD and treated with any modality of RRT; (2) PRO was used as outcome; (3) the purpose was to investigate the RS in participants; (4) the manuscript should be an original article published in English and Chinses. The exclusion criteria 
were: (1) methodology, review, editorial, commentary, and congress abstract; (2) lack of clear definition and/or sufficient evidence of the presence and category of RS. Citations were imported into EndNote X9. Duplicated articles were removed. Two reviewers performed the first screening of titles and abstracts and identified potentially relevant studies. Then full text of studies was reviewed, and disagreement was resolved by their consensus.

\section{Data extraction and quality assessment}

Two reviewers independently performed the study selection in an unblended standardized manner. They extracted the first author's name, publication year, study purpose, study design, sample size, participant details, treatment type, assessment duration, measures of PRO, methods of examining RS, main results and conclusions. The titles and abstracts of all citations were evaluated to identify articles for systemic review. Two reviewers cross-checked the included data and evaluated the quality of the eligible articles according to the National Institutes of Health Quality Assessment Tool for Observational Cohort and Cross-Sectional Studies [24]. Fourteen items were considered in the tool, including the assessment for the research question, representativeness of study samples, response rate of eligible participants, exposure and outcome measures, the association between exposure and outcomes and adjustment for confounding variables. All included studies were scored as poor ( $0-4$ positive responses), fair (5-9 positive responses) or good (10-14 positive responses). Any disagreement between the reviewers were resolved through their discussion.

\section{Results}

\section{Literature search}

The search yielded a total of 121 articles through five databases. After removing 36 duplicates, 85 studies were initially screened for titles and abstracts, and then six potential articles were screened for full text, together with other two studies identified by manual search. Finally, four articles were included for they met the eligibility criteria. The flow chart of the literature review and article selection process was shown in Fig. 1.

\section{Study characteristics}

Table 1 displays the characteristics of the included studies. These four articles, including a doctoral dissertation, were published or approved between 2000 and 2015. Among them, two were conducted in the Taiwan, China [15-16], and the others were in Nederland [17] and the United States [11], respectively. Three studies were quantitative prospective cohort studies [15-17], and the remaining one was a qualitative perspective cross-sectional study [11]. A broad range of instruments were applied for QoL measures, namely visual analog scale, time trade-off, standard gamble, individual interviews, the Schedule for Evaluation of Individual Quality of Life-Direct Weighting, and the ideal scale [11, 15-17]. Apart from QoL, other outcomes such as positive and negative effects and satisfaction with life were also examined in one study [15]. Among the three cohort studies, the duration between baseline and follow-up assessments ranged from three months to 18 months [15-17]. In the cross-sectional study, 31 individual interviews of patients and a part of family members were conducted over 2 years. A total of 286 individuals were included in this review but the sample size of each study was no more than 100, with the smallest sample size of Barbara et al. [11] (20 patients and 11 family members) and the largest of Liu, Nai Chih (93 patients) [15]. 
Table 1

Characteristics of studies included

\begin{tabular}{|c|c|c|c|c|c|c|c|}
\hline Study & $\begin{array}{l}\text { Publication } \\
\text { year }\end{array}$ & Design & Country & $\begin{array}{l}\text { Qol } \\
\text { measurement }\end{array}$ & $\begin{array}{l}\text { Other } \\
\text { outcomes }\end{array}$ & $\begin{array}{l}\text { Assessment } \\
\text { duration }\end{array}$ & $\begin{array}{l}\text { Sample } \\
\text { size }\end{array}$ \\
\hline \multirow[t]{4}{*}{$\begin{array}{l}\text { Postulart } \\
\text { et al. }\end{array}$} & 2000 & $\begin{array}{l}\text { Quantitative, } \\
\text { prospective, } \\
\text { cohort }\end{array}$ & Nederland & VAS, TTO, SG & None & $\begin{array}{l}\text { T0: before } \\
\text { combined } \\
\text { pancreas- } \\
\text { kidney } \\
\text { transplants }\end{array}$ & $\begin{array}{l}22 \\
\text { patients, } \\
55 \\
\text { proxies }\end{array}$ \\
\hline & & & & & & $\begin{array}{l}\text { T1: } 5 \\
\text { months } \\
\text { after T0 }\end{array}$ & \\
\hline & & & & & & $\begin{array}{l}\text { T2: } 12 \\
\text { months } \\
\text { after T0 }\end{array}$ & \\
\hline & & & & & & $\begin{array}{l}\text { T3: } 18 \\
\text { months } \\
\text { after T0 }\end{array}$ & \\
\hline $\begin{array}{l}\text { Barbara } \\
\text { et al. }\end{array}$ & 2013 & $\begin{array}{l}\text { Qualitative, } \\
\text { prospective, } \\
\text { cross- } \\
\text { sectional, }\end{array}$ & $\begin{array}{l}\text { The } \\
\text { United } \\
\text { States }\end{array}$ & Interviews & None & $\begin{array}{l}\text { Not } \\
\text { applicable }\end{array}$ & $\begin{array}{l}20 \\
\text { patients, } \\
11 \\
\text { family } \\
\text { members }\end{array}$ \\
\hline $\begin{array}{l}\text { Liu, Nai } \\
\text { Chih. }\end{array}$ & 2014 & $\begin{array}{l}\text { Quantitative, } \\
\text { prospective, } \\
\text { cohort }\end{array}$ & China & $\begin{array}{l}\text { SEIQol-DW, } \\
\text { ideal scale }\end{array}$ & $\begin{array}{l}\text { Positive } \\
\text { and } \\
\text { negative } \\
\text { affect, } \\
\text { satisfaction } \\
\text { with life }\end{array}$ & 3 months & $\begin{array}{l}93 \\
\text { patients }\end{array}$ \\
\hline $\begin{array}{l}\text { Liu, Nai } \\
\text { Chih et } \\
\text { al. }\end{array}$ & 2015 & $\begin{array}{l}\text { Quantitative, } \\
\text { prospective, } \\
\text { cohort }\end{array}$ & China & SEIQoI-DW & None & 3 months & $\begin{array}{l}85 \\
\text { patients }\end{array}$ \\
\hline \multicolumn{8}{|c|}{$\begin{array}{l}\text { VAS visual analog scale, TTO time tradeoff, SG standard gamble, SEIQOI-DWThe Schedule for Evaluation of } \\
\text { Individual Quality of Life-Direct Weighting, PWD people living with dialysis }\end{array}$} \\
\hline
\end{tabular}

\section{Quality assessment and Publication bias}

The quality evaluation results of the included studies were presented in Table 2. Two studies were scored as "good" and the rest were scored as "fair", indicating a moderate to low risk of bias. Items receiving the least positive responses were "different levels of the exposure to interest" and "the follow-up rate". The exposures of these studies could not be divided into multiple categories, so all responses to these items were "not applicable". Another limitation of the included studies was low follow-up rates. The agreement of two reviewers reached an acceptable level through discussion and consultation. 
Table 2

Quality assessment of included studies

Criteria

$\begin{array}{llll}\text { Postulart } & \text { Barbara } & \text { Liu, } & \text { Liu, } \\ \text { et al. } & \text { et al. } & \text { Nai } & \text { Nai }\end{array}$

Chih. Chih

et al.

1. Was the research question or objective in this paper clearly stated? Yes Yes Yes

2. Was the study population clearly specified and defined? Yes Yes Yes Yes

3. Was the participation rate of eligible persons at least 50\%? $\quad$ NR $\quad$ Yes $\quad$ Yes Yes

4. Were all the subjects selected or recruited from the same or similar $\quad$ NR $\quad$ No $\quad$ Yes Yes populations? Were inclusion and exclusion criteria for being in the study prespecified and applied uniformly to all participants?

5. Was a sample size justification, power description, or variance and $\quad$ No $\quad$ Yes No No effect estimates provided?

6. For the analyses in this paper, were the exposure(s) of interest $\quad$ Yes $\quad$ No $\quad$ Yes Yes measured prior to the outcome(s) being measured?

7. Was the timeframe sufficient so that one could reasonably expect to Yes No Nes Yes see an association between exposure and outcome if it existed?

8. For exposures that can vary in amount or level, did the study examine $\quad$ NA NA NA NA different levels of the exposure as related to the outcome (e.g., categories

of exposure, or exposure measured as continuous variable)?

9. Were the exposure measures (independent variables) clearly defined, $\quad$ CD $\quad$ Yes $\quad$ Yes Yes valid, reliable, and implemented consistently across all study

participants?

10. Was the exposure(s) assessed more than once over time?

Yes Yes Yes Yes

11. Were the outcome measures (dependent variables) clearly defined, $\quad$ Yes $\quad$ CD $\quad$ Yes Yes valid, reliable, and implemented consistently across all study participants?

12. Were the outcome assessors blinded to the exposure status of participants?

13. Was loss to follow-up after baseline $20 \%$ or less?

14. Were key potential confounding variables measured and adjusted statistically for their impact on the relationship between exposure(s) and outcome(s)?

Total number of positive responses and assessed quality rating.

6, fair

6 , fair

10, 10,

good good

NA not applicable, NR not reported, $C D$ cannot determine

\section{Sample characteristics}

Table 3 presents the characteristics of the patients. A total of 220 patients were included and the mean age of them ranged from 39.94 to 80 years old. All four studies enrolled males and females, and male participants accounted for over a percentage of fifty in most studies. The treatment of patients included combined pancreas-kidney transplantations, hemodialysis and peritoneal dialysis. Patients in the study of Postulart et al. experienced pre-tests before transplantation [17]. In the rest three studies, two enrolled patients receiving dialysis for no more than 12 
months [15-16], and one included patient that underwent dialysis for at least six months and were treated for an average of 34 months [11].

Table 3

Characteristics of patients

\begin{tabular}{|c|c|c|c|c|}
\hline Study & Age & Sex, female, $n(\%)$ & Treatment & $\begin{array}{l}\text { Months since patients } \\
\text { receiving dialysis }{ }^{\text {a }}\end{array}$ \\
\hline $\begin{array}{l}\text { Postulart } \\
\text { et al. }\end{array}$ & $\begin{array}{l}\text { Patients, mean }=39.94 \text { years } \\
\text { Family members, mean }= \\
26.74 \text { years }\end{array}$ & $\begin{array}{l}\text { Patients, } \\
4(18.18 \%) \\
\text { Proxies, } \\
32(58.18 \%)\end{array}$ & $\begin{array}{l}\text { Combined } \\
\text { pancreas-kidney } \\
\text { ransplants }\end{array}$ & Not applicable ${ }^{b}$ \\
\hline $\begin{array}{l}\text { Barbara } \\
\text { et al. }\end{array}$ & $\begin{array}{l}\text { Mean }=80 \text { years }(S D=6.7 \\
\text { range of } 70-100)\end{array}$ & $12(44.44 \%)$ & Dialysis & $\begin{array}{l}\text { Receiving dialysis for at } \\
\text { least } 6 \text { months, Mean = } 34 \\
\text { months }\end{array}$ \\
\hline \multirow[t]{3}{*}{$\begin{array}{l}\text { Liu, Nai } \\
\text { Chih. }\end{array}$} & $\begin{array}{l}\text { CKD patients without } \\
\text { dialysis, mean }=55.36 \\
\text { years }(S D=11.97)\end{array}$ & $\begin{array}{l}\text { CKD patients } \\
\text { without } \\
\text { dialysis,18(50\%), }\end{array}$ & \multirow[t]{3}{*}{$H D, P D$} & \multirow[t]{3}{*}{$\begin{array}{l}\text { Receiving dialysis for no } \\
\text { more than } 12 \text { months }\end{array}$} \\
\hline & $\begin{array}{l}\text { HD patients, mean = } 56.14 \\
\text { years }(S D=15.74)\end{array}$ & $\begin{array}{l}\text { HD patients, } \\
12(42.9 \%)\end{array}$ & & \\
\hline & $\begin{array}{l}\text { PD patients, mean }= \\
50.88(\mathrm{SD}=15.01)\end{array}$ & $\begin{array}{l}\text { PD patients, } \\
14(48.3 \%)\end{array}$ & & \\
\hline \multirow[t]{2}{*}{$\begin{array}{l}\text { Liu, Nai } \\
\text { Chih et } \\
\text { al. }\end{array}$} & $\begin{array}{l}\text { CKD patients without } \\
\text { dialysis, mean }=56.50 \\
\text { years }(S D=11.77)\end{array}$ & $\begin{array}{l}\text { CKD patients } \\
\text { without } \\
\text { dialysis,14(50\%), }\end{array}$ & \multirow[t]{2}{*}{$H D, P D$} & \multirow[t]{2}{*}{$\begin{array}{l}\text { Receiving dialysis for no } \\
\text { more than } 12 \text { months }\end{array}$} \\
\hline & $\begin{array}{l}\text { CKD patients with dialysis, } \\
\text { mean }=48.05(S D=16.12)\end{array}$ & $\begin{array}{l}\text { CKD patients } \\
\text { with dialysis, } \\
26(45.6 \%)\end{array}$ & & \\
\hline \multicolumn{5}{|c|}{$\begin{array}{l}S D \text { standard deviation, } C K D \text { chronic renal disease, } H D \text { hemodialysis, } P D \text { peritoneal dialysis, } R R T \text { renal replacement } \\
\text { therapy }\end{array}$} \\
\hline \multicolumn{5}{|c|}{ a It means how long had they been receiving dialysis until they were enrolled in the research } \\
\hline
\end{tabular}


Table 4

RS detection methods, existence of RS, type of detected RS and RS indicators

\begin{tabular}{|lllll|}
\hline Study & $\begin{array}{l}\text { RS detection } \\
\text { methods }\end{array}$ & $\begin{array}{l}\text { Presence } \\
\text { of RS }\end{array}$ & $\begin{array}{l}\text { Type of detected } \\
\text { RS }\end{array}$ & Main results \\
\hline $\begin{array}{l}\text { Postulart } \\
\text { et al. }\end{array}$ & Then-test & Significant & Not specified & $\begin{array}{l}\text { RS occurred in the adaption to disease, which } \\
\text { enhanced the prospectively assessed } \\
\text { pretreatment QOL. }\end{array}$ \\
\hline $\begin{array}{l}\text { Barbara } \\
\text { et al. }\end{array}$ & $\begin{array}{l}\text { Then-test, } \\
\text { individualized } \\
\text { measures }\end{array}$ & Exist & $\begin{array}{l}\text { Recalibration, } \\
\text { reprioritization, } \\
\text { reconceptualization }\end{array}$ & $\begin{array}{l}\text { The PWDs recalibrated their QOL when start } \\
\text { dialysis and struggled to reconsider the } \\
\text { conception of QOL and revisited their values } \\
\text { and priorities when their health conditions and } \\
\text { function changed. }\end{array}$ \\
\hline $\begin{array}{l}\text { Liu, Nai } \\
\text { Chih. }\end{array}$ & $\begin{array}{l}\text { Then-test, } \\
\text { individualized } \\
\text { measures }\end{array}$ & Significant & $\begin{array}{l}\text { Recalibration, } \\
\text { reprioritization }\end{array}$ & $\begin{array}{l}\text { The effect of recalibration on QOL was the } \\
\text { most significant. Maintaining a positive } \\
\text { expectation towards life is an important factor } \\
\text { in the self-regulation of patients with chronic } \\
\text { diseases. }\end{array}$ \\
\hline $\begin{array}{l}\text { Liu, Nai } \\
\text { Chih et } \\
\text { al. }\end{array}$ & $\begin{array}{l}\text { Then-test, } \\
\text { individualized } \\
\text { measures }\end{array}$ & Significant & $\begin{array}{l}\text { Recalibration, } \\
\text { reconceptualization }\end{array}$ & $\begin{array}{l}\text { It is the gap between present and expected } \\
\text { status but not the different stages of the } \\
\text { disease and modalities of treatment lead } \\
\text { patients to change their standard and concept } \\
\text { quality of life. }\end{array}$ \\
\hline RS response shift, $P W D$ people living with dialysis, $C K D$ chronic renal disease, \\
\hline ReSUlts Of individual Studies
\end{tabular}

Table 3 shows the detection methods of RS, the presence of RS, the types of detected RS, and the main findings of the four studies. All four studies used the "then-test" methods and three of them also applied individualized measures including interviews, SEIQol-DW and ideal scale to examine response shift $[11,15-17]$. The detection was performed according to the study design, and there were no model-based approaches such as relative importance analysis and mixed-effects regression [25]. As for the presence and types of response shift, all studies reported a response shift. Barbara et al. found three kinds of response shift on patients with dialysis [11]. Among the rest quantitative studies, response shift with statistical significance was reported and the most common type of response shift detected was recalibration [15-17]. Postulart et al. [17] indicated that the response shift occurs in the adaption to disease, which may exaggerate the prospectively evaluated QoL. Barbara et al. [11] found that patients with dialysis recalibrated their QoL when they started dialysis. In this process, they managed to reconsider the conception of QoL and revisited their values and priorities when their health conditions and physical function changed. As the study of Liu, Nai Chih in 2014 showed [15], the effect of recalibration on QoL was the most significant among all kinds of response shift. What's more, chronic kidney disease (CKD) patients and those with dialysis in Taiwan tended to change the nominations for essential areas of their life rather than lower their expectations to improve QoL. Maintaining a positive hope towards life is a crucial factor in the self-regulation of patients with chronic diseases. Liu, Nai Chih et al. [16] revealed that the gap between present and expected status would lead patients to changing their standard and concept of good-quality life. However, different stages of disease and modalities of treatment may have no impact on the response shift of patients with CKD.

\section{Discussion}

This study reviewed articles that evaluated the response shift among patients with end-stage renal disease. In the four included studies, "then-test" was most commonly employed. Though response shift was proved existent or even 
significant in all studies, due to statistical approaches, we were unable to obtain the details about the significance testing. In two of three longitudinal studies, QoL had been assessed twice and the interval time was three months. More assessment should be considering in the future studies, such as setting additional time points and periods, to investigate the change of RS over time $[14,26]$. Except for one study in which the initial QoL assessment was conducted before the kidney transplantation [17], the other three studies all included patients that had already received dialysis for several months in the baseline [11, 15-16]. Considering that patients may report a high level of response shift in their primary stage after diagnosis and in a short time after first treatment [27], response shift assessment should be administered at the time of diagnosis and the initial treatment in future research. Besides, patients with dialysis were the most commonly enrolled populations in the four included studies. Given that renal replacement therapy modalities among patients with ESRD are various and have remarkable impacts on patients-reported quality of life [7, 28-29], the RS mechanism among patients with different RRT modalities need to be compared and discussed.

It is crucial to assess the presence and magnitude of response shift because it may cover up the real change of QoL and provide information about how the patients get used to disease. A study conducted in patients receiving pancreas-kidney transplantation revealed that their re-evaluated QoL after a successful transplantation was significantly lower than the prospective assessment before the transplantation, indicating that patients with chronic disease had an excellent capacity to adapt to their conditions [30]. A deeper understanding of RRT treatment's psychological impact may help patients live with ESRD better [12]. This finding can be used to avoid negative RS and induce positive RS, thus helping patients recognize the change in health status and signal of recovery [31]. Therefore, more well-designed studies should be to conduct to deepen the understanding of response shift among patients with ESRD.

There are two common methods for response shift detection [25]. One is design-based approaches, including retrospective pre-test design and individualized measures, which was widely used in the four reviewed articles. The other is model-based statistical approaches, such as structural equation model (SEM) method, relative importance analysis, and item response theory. A review conducted by Sajobi et al. reported an increasing number of sophisticated empirical methods in RS detection [22]. The advanced statistical purposes get rid of the recall bias of design-based approaches and are widely used in secondary longitudinal-data analyses, which we hope will be utilized in more studies among patients with ESRD. Distinguishing and correlating response shift at the group level and the individual level is another critical issue [32]. Sawatzky R thought the individual differences of RS could be regarded as heterogeneity because the presence and forms of RS varied in people [33]. In the theoretical model of RS of Sprangers $\mathrm{M}$ et al., antecedents such as personality and spiritual practice are among the five important elements of RS [3]. However, as an individual phenomenon, the response shift is usually identified at a group level through the quantitative statistical methods [31]. To solve this problem, Aburub AS et al. proposed to add a qualitative measure in the quantitative study to enhance the finding of RS [34]. On all accounts, when deciding RS detection methods, factors such as research aims, sample characteristics and variable disruptions should be considered.

As for the factors of response shift, Barbara et al. showed the impact of disease trajectory [11]. The study reported four themes of patients on dialysis in different stages, which included "the primary adjustment", "thriving", "surviving" and "end-stage. The changes of themes indicated their evident response shift as the health status and circumstances changed. The conclusion was similar to that of Yang $\mathrm{J}$ et at., which found that the patients with Parkinson's disease recalled their HRQoL differently according to their disease trajectory, and that the retrospective QoL assessments between "decliners" and "improvers" was different [35]. Besides, Liu, Nai Chih et al. revealed that have-want discrepancy was another catalyst of the response shift mechanism. Further research should focus more on patients with high have-want discrepancy and discuss how to encourage them to change their goals and life center. 
As the previous research revealed, PRO has played a role in weighing up costs and benefits of therapeutic regimen, improving satisfaction, enhancing communication, and engaging patients in successfully shared decision making [36-38]. The need to better understand how diseases and treatment impact patients' lives, wellbeing and functional performance is well acknowledged [39-40]. However, the psychometric robustness to measure PRO may influence PRO's credibility and interfere with its effects [41], which is also required for more scientific rigor by The US Food and Drug Administration [42]. Self-reported HRQoL is an example of PRO assessment based on patients' perception of their physical, social, and mental wellbeing under the impact on their health condition or medical treatment [43]. Some researchers viewed response shift as an unintentional side effect of PRO instruments [25] and how it influenced the HRQoL assessment. It depends on the complexity of target complexity and the construct dimensionality of tools [44]. Designing an HRQoL instrument with the bias of RS eliminated may be a straightforward countermeasure. Still, when we view inducing RS as an intervention for psychological adjustment, it's better to design a method to examine the effects of RS [44]. Shared decision-making (SDM) provides a new form of RS intervention. It stresses the selfevaluation and preferences of patients and may contribute to explaining the impact of RS and improving the use of PRO [45]. To our knowledge, studies intervening in response shift are few and have never been done among patients with ESRD. Notably, the intervening measure to response shift such as SDM or psychological counseling may help patients better adapt to illness and break the natural coping mechanism such as changing treatment or rebuilding their belief in life. Thus, the disclosure and explanation of key information, including potential consequences, should be provided to patients.

Our study is the first systematic review of the response shift among patients with ESRD. It may contribute to more focus on the study of RS in the context of ESRD. Optimized research design, advanced RS detection methods and effective intervention programs should be developed in this area. Some limitations of this systematic review should also be noted. First, we included studies in Chinese but excluded other foreign language papers according researcher's own language background. Thus, some potentially relevant studies in other languages may be missed in the search of electronic databases (PubMed, EMBASE, EBSCO host, Web of Science, and Cochrane Library) and manual review. What's more, all of the four included studies chose "then-test" to detect their response shift, which may be influenced by the recall bias. The interference of recall bias may be exceptionally substantial in the study conducted by Barbara et al., in which patients had been on dialysis for an average of 34 months [11].

\section{Conclusion}

The assessments of health-related quality of life among patients with ESRD are affected by response shift. The phenomenon of response shift in patients with ESRD need more attention and the real status of quality of life and the impact of response shift should be distinguished. Furthermore, given that the response shift is a regulating measure, we recommend utilizing response shifts to modify interventions to promote recovery and help patients adapt to ESRD better.

\section{Declarations}

\section{Acknowledgement}

Not applicable

\section{Authors' contributions}

Zheng Yang and Fei Yang designed the study. Zheng Yang and Xiaoru Feng analyzed the data and drafted the manuscript. Fei Yang and Lu Cheng critically revised the manuscript. Pusheng Wang provided critical review, advice 
and consultation throughout the writing of the manuscript. All authors approved the final version of the manuscript.

\section{Funding}

This study was funded by the 2018 Ministry of Education Humanities and Social Sciences General Project "Technical Sociology Research on Chinese Organ Donation from a Multidimensional Perspective" [18YJA840011] and Shenzhen Key Research Base of Humanities and Social Sciences.

\section{Availability of data and materials}

All data generated or analyzed during this study are included in this published article and its supplementary information files.

\section{Ethics approval and consent to participate}

Not applicable

\section{Consent for publication}

Not applicable

\section{Competing interests}

Zheng Yang, Fei Yang, Qian Lin, Xiaoru Feng and Ying Kong declare that they have no conflict of interest. All authors have no other relevant financial interests to declare.

\section{Abbreviations}

QOL: Quality of life

ESRD: End-stage renal disease

RS: Response shift

PRO: Patient-reported outcomes

HRQoL: Health related quality of life

RRT: Renal replacement therapies

HD: Hemodialysis

PD: Peritoneal dialysis

Tx: Renal transplantation

MeSH: Medical Subject Headings

CKD: Chronic kidney disease

SEM: structural equation model 


\section{References}

1. Deshpande, P. R., Rajan, S., Sudeepthi, B. L. \& Nazir C. P., A. Patient-reported outcomes: A new era in clinical research. Perspectives in Clinical Research. 2011;2(4):137-44.

2. Lavallee, D. C., Chenok, K. E., Love, R. M., Petersen, C., Holve, E. \& Segal, C. D., et al. Incorporating Patient-Reported Outcomes Into Health Care To Engage Patients And Enhance Care. Health Affairs. 2016;35(4):575-82.

3. Sprangers, M. \& Schwartz, C. E. Integrating response shift into health-related quality of life research: a theoretical model. Social Science \& Medicine. 1999;48(11):1507-15.

4. Schwartz, C. E. \& Sprangers, M. A. G. Methodological approaches for assessing response shift in longitudinal health-related quality-of-life research. Social Science \& Medicine. 1999;48(11):1531-48.

5. Ten Ham, R. M. T., Broering, J. M., Cooperberg, M. R., Carroll, P. \& Wilson, L. S. Understanding the Major Factors Affecting Response Shift Effects on Health-Related Quality of Life: What the Then-Test Measures in a Longitudinal Prostate Cancer Registry. Clinical Genitourinary Cancer. 2020;18(1): e21-e27.

6. Schwartz, C. E., Bode, R., Repucci, N., Becker, J., Sprangers, M. A. G. \& Fayers, P. M. The clinical significance of adaptation to changing health: A meta-analysis of response shift. Quality of Life Research. 2006;15(9):1533-50.

7. Robinson, B. M., Akizawa, T., Jager, K. J., Kerr, P. P. G. \& Pisoni, R. L. Factors affecting outcomes in patients reaching end-stage kidney disease worldwide: Differences in access to renal replacement therapy, modality use, and haemodialysis practices. Lancet. 2016;388(10041).

8. Finkelstein, F. O., Wuerth, D. \& Finkelstein, S. H. Health related quality of life and the CKD patient: challenges for the nephrology community. Kidney International.2009;76(9):946-52.

9. Auneau-Enjalbert, L., Hardouin, J., Blanchin, M., Giral, M., Morelon, E. \& Cassuto, E., et al. Comparison of longitudinal quality of life outcomes in preemptive and dialyzed patients on waiting list for kidney transplantation. Quality of Life Research. 2020;29(4):959-70.

10. Reid, C., Seymour, J. \& Jones, C. A Thematic Synthesis of the Experiences of Adults Living with Hemodialysis. Clinical Journal of the American Society of Nephrology. 2016;11(7):1206-18.

11. BA, E., CE, G., PM, L. \& TE, R. Shifting responses in quality of life: people living with dialysis. Quality of Life Research. 2014;23:1497-1504.

12. Véronique Sébille, C. A. J. H. Prospective, multicenter, controlled study of quality of life, psychological adjustment process and medical outcomes of patients receiving a preemptive kidney transplant compared to a similar population of recipients after a dialysis period of less than three years - The PreKit-QoL study protocol. BMC Nephrol. 2016;17(11).

13. Chao, L. F., Fan, J. Y., Chung, F. F. \& Lam, H. B. The Effect of Response Shift on Quality of Life among Cancer Patients: A Systematic Review. Open Access Library Journal. 2014;01(9):1-13.

14. Ilie, G., Bradfield, J., Moodie, L., Lawen, T., Ilie, A. \& Lawen, Z., et al. The Role of Response-Shift in Studies Assessing Quality of Life Outcomes Among Cancer Patients: A Systematic Review. Frontiers in Oncology. 2019;9:783.

15. Liu, N. C. Using the SEIQoL-DW to Detect the Qaulity of Life in Taiwan Dialysis Patients $\triangle$ Application of the Theory of Response Shift [in Chinese]. http://nccur.lib.nccu.edu.tw/handle/140.119/63699 (2014). Accessed 05 April 2020.

16. Nai-Chih Liu, J. F. I. L. Response Shift in Patients with Chronic Kidney Disease: The Influence of a Have-Want Discrepancy [in Chinese]. Chinese Journal of Psychology. 2015;28(2):257-80. 
17. Postulart, D. \& Adang, E. M. M. Response Shift and Adaptation in Chronically III Patients. Medical Decision Making. 2020;20(2):186-93.

18. Sajobi, T. T., Fiest, K. M. \& Wiebe, S. Changes in quality of life after epilepsy surgery: the role of reprioritization response shift. Epilepsia. 2014;55(9):1331-38.

19. Schwartz, C. E., Bode, R., Repucci, N., Becker, J., Sprangers, M. A. G. \& Fayers, P. M. The clinical significance of adaptation to changing health: A meta-analysis of response shift. Quality of Life Research. 2006;15(9):1533-50.

20. Donohoe, J. E. To what extent can response shift theory explain the variation in prostate cancer patients' reactions to treatment side-effects? A review. Quality of Life Research. 2011; 20(2):161-7.

21. Powden, C. J., Hoch, M. C. \& Hoch, J. M. Examination of Response Shift after Rehabilitation for Orthopedic Conditions: A Systematic Review. Journal of Sport Rehabilitation. 2018;27(5):469-79.

22. Sajobi, T. T., Brahmbatt, R., Lix, L. M., Zumbo, B. D. \& Sawatzky, R. Scoping review of response shift methods: current reporting practices and recommendations. Quality of Life Research. 2018;27(5):1133-46.

23. Moher, D., Liberati, A., Tetzlaff, J. \& Altman, D. G. P. G. Preferred reporting items for systematic reviews and metaanalyses: the PRISMA statement. PLoS Med 6: e1000097. Open Medicine. 2009;3(3):e123-e130.

24. National Institutes of Health/National Heart, Lung, and Blood Institute. Quality Assessment Tool for Observational Cohort and Cross-Sectional Studies 2015 [Available from: https://www.nhlbi.nih.gov/health-topics/study-qualityassessment-tools]. Accessed 6 July 2020.

25. Sawatzky, R., Sajobi, T. T., Brahmbhatt, R., Chan, E. K. H., Lix, L. M. \& Zumbo, B. D. Longitudinal Change in Response Processes: A Response Shift Perspective. In Zumbo, B. D. \& Hubley, A. M, editors. Understanding and Investigating Response Processes in Validation Research. Springer International Publishing,Cham. 2017. p. 251276.

26. Yang, J., Hanna-Pladdy, B., Gruber-Baldini, A. L., Barr, E., von Coelln, R. \& Armstrong, M. J., et al. Response shift The experience of disease progression in Parkinson disease. Parkinsonism \& Related Disorders. 2017;36:52-56.

27. Broberger, E., Sprangers, M. \& Tishelman, C. Do internal standards of quality of life change in lung cancer patients? Nursing Rsearch. 2006;55(4):274-82.

28. Liu, F. X., Gao, X., Inglese, G., Chuengsaman, P., Pecoits-Filho, R. \& Yu, A. A Global Overview of the Impact of Peritoneal Dialysis First or Favored Policies: An Opinion. Peritoneal Dialysis International: Journal of the International Society for Peritoneal Dialysis. 2015;35(4):406-20.

29. Matas, A. J. Increased ESRD and mortality risk for kidney donors? Nature Reviews Nephrology. 2014;10(3):130-31.

30. Adang, E. M. M., Kootstra, G., Engel, G. L., van Hooff, J. P., Merckelbach, H. L. G. J. \& Adang, E. E. M. Do retrospective and prospective quality of life assessments differ for pancreas-kidney transplant recipients? Transplant International. 1998;11(1):11-15.

31. Mayo, N. E. Appraisal as a unifying theory of response shift: continuing the conversation. Quality of Life Research. 2019;28(10):2635-36.

32. Rapkin, B. D. \& Schwartz, C. E. Advancing quality-of-life research by deepening our understanding of response shift: a unifying theory of appraisal. Quality of Life Research. 2019;28(10):2623-30.

33. Sawatzky, R. Relating response shift and cognitive appraisal to measurement validation. Quality of Life Research. 2019;28(10):2633-34.

34. Aburub, A. S., Gagnon, B., Ahmed, S., Rodríguez, A. M. \& Mayo, N. E. Impact of reconceptualization response shift on rating of quality of life over time among people with advanced cancer. Support Care Cancer. 2018;26(9):306371.

Page 13/19 
35. Yang, J., Hanna-Pladdy, B., Gruber-Baldini, A. L., Barr, E., von Coelln, R. \& Armstrong, M. J., et al. Response shift The experience of disease progression in Parkinson disease. Parkinsonism Relat Disord. 2017;36:52-56.

36. Peeters, G., Barker, A. L., Talevski, J., Ackerman, I. \& Mcneil, J. J. Do patients have a say? A narrative review of the development of patient-reported outcome measures used in elective procedures for coronary revascularisation. Quality of Life Research. 2018;27(1):1369-80.

37. Chen, J., Ou, L. \& Hollis, S. J. A systematic review of the impact of routine collection of patient reported outcome measures on patients, providers and health organisations in an oncologic setting. Bmc Health Services Research. 2013;13(1):211.

38. Noonan, V. K., Lyddiatt, A., Ware, P., Jaglal, S. B. \& Ahmed, S. Montreal Accord on Patient-Reported Outcomes Use Series-Paper 3: Patient Reported Outcomes (PRO) Can Facilitate Shared Decision-Making and Guide SelfManagement. Journal of Clinical Epidemiology. 2017:89.

39. Wiklund, I. Assessment of patient-reported outcomes in clinical trials: the example of health-related quality of life. Fundamental \& Clinical Pharmacology. 2004;18(3):351-63.

40. Stull, D. E., Leidy, N. K., Jones, P. W. \& Ståhl, E. Measuring functional performance in patients with COPD: A discussion of patient-reported outcome measures. Current Medical Research \& Opinion. 2007;23(11):2655-65.

41. Kotronoulas, G., Kearney, N., Maguire, R., Harrow, A., Di Domenico, D. \& Croy, S., et al. What Is the Value of the Routine Use of Patient-Reported Outcome Measures Toward Improvement of Patient Outcomes, Processes of Care, and Health Service Outcomes in Cancer Care? A Systematic Review of Controlled Trials. Journal of Clinical Oncology. 2014;32(14):1480.

42. McLeod, L. D., Coon, C. D., Martin, S. A., Fehnel, S. E. \& Hays, R. D. Interpreting patient-reported outcome results: US FDA guidance and emerging methods. Expert Review of Pharmacoeconomics \& Outcomes Research. 2011;11(2):163-9.

43. Finkelstein, F. O., Arsenault, K. L., Taveras, A., Awuah, K. \& Finkelstein, S. H. Assessing and improving the healthrelated quality of life of patients with ESRD. Nature Reviews Nephrology. 2012;8(12):718-24.

44. Vanier, A., Leplege, A., Hardouin, J. B., Sebille, V. \& Falissard, B. Semantic primes theory may be helpful in designing questionnaires such as to prevent response shift. J Clin Epidemiol. 2015;68(6):646-654.

45. Hartog, I. D., Willems, D. L., van den Hout, W. B., Scherer-Rath, M., Oreel, T. H. \& Henriques, J. P. S., et al. Influence of response shift and disposition on patient-reported outcomes may lead to suboptimal medical decisions: a medical ethics perspective. BMC Medical Ethics. 2019;20(1):61.

\section{Tables}

Table 1 Characteristics of studies included 


\begin{tabular}{|c|c|c|c|c|c|c|c|}
\hline Study & $\begin{array}{l}\text { Publication } \\
\text { year }\end{array}$ & Design & Country & $\begin{array}{l}\text { Qol } \\
\text { measurement }\end{array}$ & $\begin{array}{l}\text { Other } \\
\text { outcomes }\end{array}$ & $\begin{array}{l}\text { Assessment } \\
\text { duration }\end{array}$ & $\begin{array}{l}\text { Sample } \\
\text { size }\end{array}$ \\
\hline $\begin{array}{l}\text { Postulart } \\
\text { et al. }\end{array}$ & 2000 & $\begin{array}{l}\text { Quantitative, } \\
\text { prospective, } \\
\text { cohort }\end{array}$ & Nederland & $\begin{array}{l}\text { VAS, TTO, } \\
\text { SG }\end{array}$ & None & $\begin{array}{l}\text { T0: before } \\
\text { combined } \\
\text { pancreas- } \\
\text { kidney } \\
\text { transplants } \\
\text { T1: } 5 \\
\text { months } \\
\text { after T0 } \\
\text { T2: } 12 \\
\text { months } \\
\text { after T0 } \\
\text { T3: } 18 \\
\text { months } \\
\text { after T0 }\end{array}$ & $\begin{array}{l}22 \\
\text { patients, } \\
55 \\
\text { proxies }\end{array}$ \\
\hline $\begin{array}{l}\text { Barbara } \\
\text { et al. }\end{array}$ & 2013 & $\begin{array}{l}\text { Qualitative, } \\
\text { prospective, } \\
\text { cross- } \\
\text { sectional, }\end{array}$ & $\begin{array}{l}\text { The } \\
\text { United } \\
\text { States }\end{array}$ & Interviews & None & $\begin{array}{l}\text { Not } \\
\text { applicable a }\end{array}$ & $\begin{array}{l}20 \\
\text { patients, } \\
11 \\
\text { family } \\
\text { members }\end{array}$ \\
\hline $\begin{array}{l}\text { Liu, Nai } \\
\text { Chih. }\end{array}$ & 2014 & $\begin{array}{l}\text { Quantitative, } \\
\text { prospective, } \\
\text { cohort }\end{array}$ & China & $\begin{array}{l}\text { SEIQol-DW, } \\
\text { ideal scale }\end{array}$ & $\begin{array}{l}\text { Positive and } \\
\text { negative } \\
\text { affect, } \\
\text { satisfaction } \\
\text { with life }\end{array}$ & 3 months & $\begin{array}{l}93 \\
\text { patients }\end{array}$ \\
\hline $\begin{array}{l}\text { Liu, Nai } \\
\text { Chih et } \\
\text { al. }\end{array}$ & 2015 & $\begin{array}{l}\text { Quantitative, } \\
\text { prospective, } \\
\text { cohort }\end{array}$ & China & SEIQol-DW & None & 3 months & $\begin{array}{l}85 \\
\text { patients }\end{array}$ \\
\hline
\end{tabular}

VAS visual analog scale, TTO time tradeoff, SG standard gamble, SEIQol-DW The Schedule for Evaluation of Individual Quality of Life-Direct Weighting, PWD people living with dialysis

a 31 individual interviews were conducted over two years in the cross-sectional study

Table 2 Quality assessment of included studies 
1. Was the research question or objective in this paper clearly stated?

2 . Was the study population clearly specified and defined?

3. Was the participation rate of eligible persons at least $50 \%$ ?

4. Were all the subjects selected or recruited from the same or similar NR populations? Were inclusion and exclusion criteria for being in the study prespecified and applied uniformly to all participants?

5 . Was a sample size justification, power description, or variance and effect estimates provided?

6. For the analyses in this paper, were the exposure(s) of interest measured prior to the outcome(s) being measured?

7. Was the timeframe sufficient so that one could reasonably expect to see an association between exposure and outcome if it existed?

8. For exposures that can vary in amount or level, did the study examine different levels of the exposure as related to the outcome (e.g., categories of exposure, or exposure measured as continuous variable)?

9. Were the exposure measures (independent variables) clearly defined, valid, reliable, and implemented consistently across all study participants?

10. Was the exposure(s) assessed more than once over time?

11. Were the outcome measures (dependent variables) clearly

defined, valid, reliable, and implemented consistently across all study participants?

12. Were the outcome assessors blinded to the exposure status of participants?

13. Was loss to follow-up after baseline $20 \%$ or less?

14. Were key potential confounding variables measured and adjusted statistically for their impact on the relationship between exposure(s) and outcome(s)?

Total number of positive responses and assessed quality rating.

\begin{tabular}{|c|c|c|c|}
\hline Yes & Yes & Yes & Yes \\
\hline Yes & Yes & Yes & Yes \\
\hline NR & Yes & Yes & Yes \\
\hline NR & No & Yes & Yes \\
\hline No & Yes & No & No \\
\hline Yes & No & Yes & Yes \\
\hline Yes & No & Yes & Yes \\
\hline NA & NA & NA & NA \\
\hline CD & Yes & Yes & Yes \\
\hline Yes & Yes & Yes & Yes \\
\hline Yes & CD & Yes & Yes \\
\hline No & No & No & No \\
\hline NR & NA & No & No \\
\hline NR & No & Yes & Yes \\
\hline 6 , fair & 6 , fair & $\begin{array}{l}10, \\
\text { good }\end{array}$ & $\begin{array}{l}10, \\
\text { good }\end{array}$ \\
\hline
\end{tabular}

$N A$ not applicable, $N R$ not reported, $C D$ cannot determine

Table 3 Characteristics of patients 


\begin{tabular}{|c|c|c|c|c|}
\hline Study & Age & $\begin{array}{l}\text { Sex, female, } \\
\mathrm{n}(\%)\end{array}$ & Treatment & $\begin{array}{l}\text { Months since patients } \\
\text { receiving dialysis }{ }^{a}\end{array}$ \\
\hline $\begin{array}{l}\text { Postulart } \\
\text { et al. }\end{array}$ & $\begin{array}{l}\text { Patients, mean }=39.94 \text { years } \\
\text { Family members, } \\
\text { mean }=26.74 \text { years }\end{array}$ & $\begin{array}{l}\text { Patients, } \\
4(18.18 \%) \\
\text { Proxies, } \\
32(58.18 \%)\end{array}$ & $\begin{array}{l}\text { Combined } \\
\text { pancreas-kidney } \\
\text { ransplants }\end{array}$ & Not applicable b \\
\hline $\begin{array}{l}\text { Barbara } \\
\text { et al. }\end{array}$ & $\begin{array}{l}\text { Mean }=80 \text { years }(S D=6.7 \text {, } \\
\text { range of } 70-100)\end{array}$ & $12(44.44 \%)$ & Dialysis & $\begin{array}{l}\text { Receiving dialysis for at } \\
\text { least } 6 \text { months, Mean }=34 \\
\text { months }\end{array}$ \\
\hline $\begin{array}{l}\text { Liu, Nai } \\
\text { Chih. }\end{array}$ & $\begin{array}{l}\text { CKD patients without } \\
\text { dialysis, mean }=55.36 \\
\text { years }(S D=11.97) \\
\text { HD patients, mean }=56.14 \\
\text { years }(S D=15.74) \\
\text { PD patients, } \\
\text { mean }=50.88(S D=15.01)\end{array}$ & $\begin{array}{l}\text { CKD patients } \\
\text { without } \\
\text { dialysis,18(50\%), } \\
\text { HD patients, } \\
12(42.9 \%) \text {, } \\
\text { PD patients, } \\
14(48.3 \%)\end{array}$ & $\mathrm{HD}, \mathrm{PD}$ & $\begin{array}{l}\text { Receiving dialysis for no } \\
\text { more than } 12 \text { months }\end{array}$ \\
\hline $\begin{array}{l}\text { Liu, Nai } \\
\text { Chih et } \\
\text { al. }\end{array}$ & $\begin{array}{l}\text { CKD patients without } \\
\text { dialysis, mean }=56.50 \\
\text { years }(\mathrm{SD}=11.77) \text {, } \\
\text { CKD patients with dialysis, } \\
\text { mean }=48.05(\mathrm{SD}=16.12)\end{array}$ & $\begin{array}{l}\text { CKD patients } \\
\text { without } \\
\text { dialysis, } 14(50 \%) \text {, } \\
\text { CKD patients } \\
\text { with dialysis, } \\
26(45.6 \%)\end{array}$ & $\mathrm{HD}, \mathrm{PD}$ & $\begin{array}{l}\text { Receiving dialysis for no } \\
\text { more than } 12 \text { months }\end{array}$ \\
\hline
\end{tabular}

$S D$ standard deviation, $C K D$ chronic renal disease, $H D$ hemodialysis, $P D$ peritoneal dialysis, $R R T$ renal replacement therapy

a It means how long had they been receiving dialysis until they were enrolled in the research

$\mathrm{b}$ Assessments were started before the combined pancreas-kidney transplants

Table 4 RS detection methods, existence of RS, type of detected RS and RS indicators 


\begin{tabular}{|c|c|c|c|c|}
\hline Study & $\begin{array}{l}\text { RS detection } \\
\text { methods }\end{array}$ & $\begin{array}{l}\text { Presence } \\
\text { of } \mathrm{RS}\end{array}$ & $\begin{array}{l}\text { Type of detected } \\
\text { RS }\end{array}$ & Main results \\
\hline $\begin{array}{l}\text { Postulart } \\
\text { et al. }\end{array}$ & Then-test & Significant & Not specified & $\begin{array}{l}\text { RS occurred in the adaption to disease, } \\
\text { which enhanced the prospectively assessed } \\
\text { pretreatment QOL. }\end{array}$ \\
\hline $\begin{array}{l}\text { Barbara } \\
\text { et al. }\end{array}$ & $\begin{array}{l}\text { Then-test, } \\
\text { individualized } \\
\text { measures }\end{array}$ & Exist & $\begin{array}{l}\text { Recalibration, } \\
\text { reprioritization, } \\
\text { reconceptualization }\end{array}$ & $\begin{array}{l}\text { The PWDs recalibrated their QOL when } \\
\text { start dialysis and struggled to reconsider } \\
\text { the conception of QOL and revisited their } \\
\text { values and priorities when their health } \\
\text { conditions and function changed. }\end{array}$ \\
\hline $\begin{array}{l}\text { Liu, Nai } \\
\text { Chih. }\end{array}$ & $\begin{array}{l}\text { Then-test, } \\
\text { individualized } \\
\text { measures }\end{array}$ & Significant & $\begin{array}{l}\text { Recalibration, } \\
\text { reprioritization }\end{array}$ & $\begin{array}{l}\text { The effect of recalibration on QOL was the } \\
\text { most significant. Maintaining a positive } \\
\text { expectation towards life is an important } \\
\text { factor in the self-regulation of patients } \\
\text { with chronic diseases. }\end{array}$ \\
\hline $\begin{array}{l}\text { Liu, Nai } \\
\text { Chih et } \\
\text { al. }\end{array}$ & $\begin{array}{l}\text { Then-test, } \\
\text { individualized } \\
\text { measures }\end{array}$ & Significant & $\begin{array}{l}\text { Recalibration, } \\
\text { reconceptualization }\end{array}$ & $\begin{array}{l}\text { It is the gap between present and expected } \\
\text { status but not the different stages of the } \\
\text { disease and modalities of treatment lead } \\
\text { patients to change their standard and } \\
\text { concept quality of life. }\end{array}$ \\
\hline
\end{tabular}

$R S$ response shift, $P W D$ people living with dialysis, $C K D$ chronic renal disease,

\section{Figures}




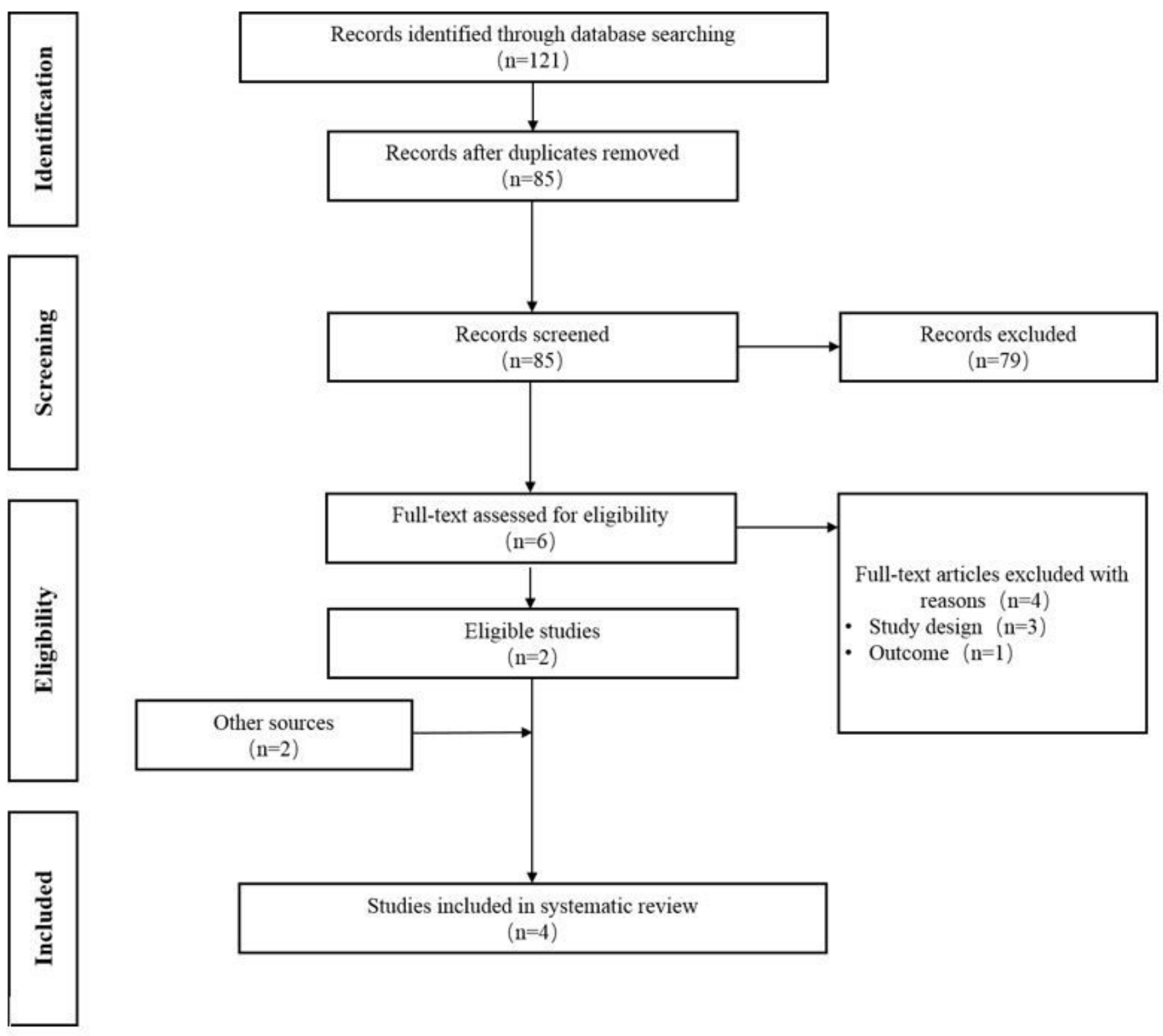

Figure 1

PRISMA process for literature review and study selection

\section{Supplementary Files}

This is a list of supplementary files associated with this preprint. Click to download.

- 20210204Additionalfile1.docx 